\title{
MODEL INTEGRASI PRAKTIK SUPERVISI KLINIS DAN LESSON STUDY GURU SEKOLAH DASAR DALAM MENCIPTAKAN PEMBELAJARAN EFEKTIF
}

\author{
Erika Mei Budiarti, Achmad Supriyanto, Burhanuddin \\ Universitas Negeri Malang, Jalan Semarang 5 Malang 65145 \\ Email: meierika09@gmail.com
}

\begin{abstract}
The aim of this research to describe about usefulness of clinical supervision techniques, lesson study, and integration of both in basic educational institutions in order to improve the professional ability of teachers in order to realize effective and efficient learning. This research was conduct at two sites, namely SD Al Irsyad Al Islamiyyah Malang and State University of Malang. Researchers used research design with descriptive qualitative approach. Data collection methods used by researchers are interviews, observation, and documentation study. Data analysis used is data reduction, data display, and data verification. Finding of this research is the new integration model of clinical supervision and lesson study to improve the professional ability of basic educational teachers.
\end{abstract}

Keywords: clinical supervision, lesson study, integration, professional

\begin{abstract}
Abstrak: Tujuan dari penelitian ini adalah untuk mendeskripsikan kebermanfaatan dari teknik supervisi klinis, lesson study, dan integrasi antara keduanya di lembaga pendidikan dasar dalam rangka meningkatkan kemampuan profesional guru guna mewujudkan pembelajaran yang efektif dan efisien. Penelitian ini dilakukan di dua situs yaitu di SD Al Irsyad Al Islamiyyah Malang dan Universitas Negeri Malang. Peneliti menggunakan rancangan penelitian dengan pendekatan kualitatif deskriptif. Metode pengumpulan data yang digunakan peneliti adalah wawancara, observasi, dan dokumentasi. Sedangkan analisis data yang digunakan adalah reduksi data, display data, dan verifikasi data. Hasil dari penelitian ini adalah temuan model baru dari hasil integrasi praktik supervisi klinis dan lesson study yang dalam rangka meningkatkan kemampuan profesional guru sekolah dasar.
\end{abstract}

Kata kunci: supervisi klinis, lesson study, integrasi, profesional

Keberadaan lembaga pendidikan akan dinilai baik dan bermutu manakala lembaga mampu menjalankan fungsi manajemen sekolahnya dengan baik. Kualitas lembaga pendidikan sendiri merupakan integrasi dari berbagai kualitas komponen manajemen sekolah. Salah satu komponen atau substansi dari manajemen sekolah yang sangat penting untuk diperhatikan dalam rangka meningkatkan kualitas lembaga adalah manajemen sumber daya manusia (SDM) bidang pendidikan. Manajemen SDM bidang pendidikan dalam hal ini yang dimaksudkan adalah manajemen pendidik (guru) dan tenaga kependidikan lembaga (staf lain). Sejalan dengan pendapat dari Saputra (2006) bahwasanya manajemen kepegawaian (pendidik dan tenaga kependidikan) adalah rangkaian kegiatan pengelolaan dimulai dari pegawai mengikuti seleksi di lembaga pendidikan sebagai calon pegawai hingga pegawai tersebut keluar (pensiun) dari lembaga pendidikan yang di dalamnya meliputi seleksi, orientasi, pengembangan, demosi, promosi, dan proses lainnya dalam rangka mencapai tujuan pendidikan (visi dan misi) yang telah ditetapkan oleh lembaga.

Tujuan pendidikan yang telah ditetapkan diantaranya adalah peserta didik mampu mencapai kriteria minimal yang telah ditetapkan oleh lembaga di masing-masing mata pelajaran. Komponen utama pencapaian tersebut adalah kemampuan seorang guru dalam melaksanakan 
tugas dan profesinya sebagai pendidik untuk dapat menyalurkan ilmu pengetahuan yang dimiliki kepada seluruh peserta didik. Guru dituntut untuk mampu melaksanakan profesinya secara profesional dengan harapan agar peserta didik juga mampu menyerap ilmu pengetahuan yang diberikan. Kompetensi guru tertuang dalam Undang-undang Nomor 14 Tahun 2005 tentang Guru dan Dosen yakni kemampuan kepribadian, kemampuan pedagogik, kemampuan profesional, dan kemampuan sosial. Kemampuan-kemampuan yang harus dimiliki oleh tenaga pendidik tersebut belum sepenuhnya mampu dikuasai oleh tenaga pedidik yang ada di lapangan saat ini. Hal ini akan memberikan dampak pada proses pembelajaran yang dilaksanakan di kelas sehingga hasil belajar peserta didikpun juga akan turut berpengaruh pada kemampuan diri masing-masing peserta didik.

Kepala sebagai pemimpin lembaga pendidikan yang sekaligus merangkap sebagai pemimpin pembelajaran di sekolah terus melakukan upaya perbaikan pengelolaan terhadap pendidik dan tenaga kependidikan di lembaga yang dipimpinnya. Berkaitan dengan hal tersebut, kepala sekolah juga berupaya untuk terus-menerus memberikan bantuan profesi kepada guru dan staf lain untuk dapat meningkatkan kemampuan profesionalnya secara mandiri, yaitu dengan cara melaksanakan kegiatan supervisi klinik kepada para pegawai secara menyeluruh. Pelaksanaan supervisi klinik saat ini diharapkan dapat dijadikan alternatif solusi terhadap kesulitan dan hambatan yang dialami oleh guru kelas maupun guru mata pelajaran ketika melaksanakan kegiatan pembelajaran di sekolah. Selain upaya yang muncul dari kepala sekolah sebagai pemimpin lembaga dalam rangka meningkatkan kemampuan profesional guru, dari pihak guru (tenaga pendidik) sendiri juga muncul satu upaya peningkatan kemampuan profesi secara kolegial yaitu melalui lesson study.

Kegiatan lesson study ini dilaksanakan secara berkelompok sesuai rumpun atau kelompok mengajar melalui diskusi ilmiah untuk mendapatkan satu rancangan perangkat pembelajaran yang terbaik yang kemudian dipraktikkan oleh satu guru/dosen model sesuai kesepakatan. Hal tersebut sejalan dengan pendapat Nur (2013) bahwasanya lesson study apabila dilaksanakan secara terusmenerus dan berkesinambungan diharapkan dapat membantu guru meningkatkan kemampuan profesionalnya termasuk dalam hal menciptakan kegiatan pembelajaran yang efektif dan edisien. Kedua teknik tersebut (supervisi klinis dan lesson study) dilaksanakan dengan harapan dapat meningkatkan kemampuan profesional utamanya pada proses transfer ilmu oleh guru kepada peserta didik di dalam kelas sehingga pembelajaran dapat berlangsung secara maksimal. Oleh sebab itu, penelitian ini mengungkap bagaimana kontribusi pelaksanaan teknik pembinaan profesional guru berupa pelaksanaan supervisi klinis dan lesson study serta integrasi antara keduanya benar-benar bermanfaat untuk memberikan solusi atas hambatan/ kendala yang terjadi.

\section{METODE}

Penelitian ini menggunakan rancangan penelitian kualitatif dengan pendekatan deskriptif dan jenis penelitian studi multi kasus di SD Al Irsyad Al Islamiyyah Malang dan Universitas Negeri Malang. Lokasi penelitian SD Al Irsyad Al Islamiyyah Malang berlokasi di Jalan Arif Margono Nomor 11 Kota Malang, sedangkan lokasi penelitian Universitas Negeri Malang berada di Jalan Semarang Nomor 5 Malang. Informan dalam penelitian ini adalah kepala sekolah, guru, dosen muda peserta lesson study, dan mahasiswa. Peneliti menggunakan teknik wawancara, observasi, dan studi dokumentas sebagai teknik pengumpul data di lapangan.

Selama proses pengambilan data dalam penelitian ini, peneliti merupakan instrumen kunci (utama). Kehadiran peneliti di lapangan mutlak harus dilaksanakan karena hal tersebut digunakan sebagai tolok ukur instrumen kunci terhadap pemahaman fenomena yang terjadi pada kejadian sebenarnya pada latar penelitian. Hal tersebut ditegaskan oleh Ulfatin (2015) bahwasanya peneliti harus dapat memahami makna peristiwa dan interaksi orangorang yang ada dalam situasi tertentu pada saat kejadian tersebut berlangsung di lapangan.

Peneliti melakukan kegiatan analisis data dimulai dari peneliti memasuki lapangan, selama peneliti berada di lapangan, dan ketika peneliti selesai melaksanakan kegiatan di lapangan. Keseluruhan kegiatan dan informasi tersebut dianalisis hingga menemukan data yang jenuh. Akan tetapi, proses analisis informasi yang diperoleh 
ditekankan pada saat peneliti berada di lapangan (selama proses penelitian berlangsung). Kegiatan pengumpulan data berlangsung bersamaan dengan proses analisis data yang dilakukan (Gunawan, 2014). Lebih lanjut terkait model analisis data yang digunakan dalam penelitian ini yaitu peneliti mereduksi data, selanjutnya melakukan penyajian (display) data, dan peneliti menarik kesimpulan (Miles, dkk., 2014).

\section{HASIL}

\section{Pelaksanaan Kegiatan Supervisi Klinis di SD Al Irsyad Al Islamiyyah Malang}

Permasalahan pembelajaran di dalam kelas di SD Al Irsyad Al Islamiyyah Malang cukup kompleks dan bervariasi di masing-masing jenjang dan mata pelajaran. Secara umum masalah yang terjadi di lapangan yaitu kesiapan guru yang kurang karena guru tidak memiliki perangkat pembelajaran yang baku sebelum mengajar, keaktifan peserta didik yang mengarah pada kegaduhan di dalam kelas selama proses pembelajaran berlangsung, kurangnya konsentrasi dan ketertarikan peserta didik untuk mengikuti pelajaran pada saat pelajaran teoritis karena kebingungan guru yang hanya menggunakan metode ceramah saja, manajemen waktu yang berlebih terkait alokasi jam pelajaran dan penggunaan waktu mengajar, serta munculnya emosi guru pada saat peserta didik tidak dapat dikondisikan dengan baik utamanya pada jam pelajaran siang hari.

Berbagai permasalahan tersebut mengiringi proses pembelajaran di semua jenjang di SD Al Irsyad Al Islamiyyah Malang. Hal tersebut apabila tidak segera ditangani akan menimbulkan dampak berkelanjutan dan kompleks bagi peserta didik dalam menerima ilmu pengetahuan bertahap dari masing-masing guru. Permasalahan tersebut dapat digolongkan menjadi dua sumber yaitu bersumber dari diri peserta didik dan dari diri guru sebagai pendidik maupun pengajar di dalam kelas. Keduanya saling berkaitan satu sama lain untuk segera ditangani agar kondisi kelas dapat terwujud dalam suasana belajar yang menyenangkan dan kondusif sehingga tujuan pembelajaran benarbenar dapat diwujudkan secara maksimal dan baik kemampuan guru maupun peserta didik juga dapat berkembang.
Upaya yang dilakukan untuk mengatasi permasalahan tersebut adalah melalui kegiatan supervisi oleh kepala sekolah kepada guru. Kegiatan supervisi klinis di SD Al Irsyad Al Islamiyyah Malang dilaksanakan melalui tiga tahap, yaitu pre conference, classroom observation, dan post observation. Dalam hal ini, guru yang melaksanakan kegiatan supervisi klinis adalah guru kelas IV, guru kelas V, dan guru mata pelajaran Pendidikan Agama Islam (PAI). Tahap awal yaitu pre conference dilaksanakan oleh masingmasing guru untuk melakukan pendekatan dan menciptakan sebuah kesepakatan dengan kepala sekolah terkait instrumen observasi dan jadwal pelaksanaan observasi maupun balikan yang akan dilaksanakan. Pada tahap ini guru dan kepala sekolah melaksanakan dalam suasana yang akrab dan terbuka. Guru menceritakan kepada kepala sekolah terkait beberapa masalah yang dialami pada saat mengajar di kelas. Selain itu guru juga menjelaskan beberapa perangkat pembelajaran yang akan digunakan dan instrumen yang telah dibuat untuk proses pelaksanaan supervisi klinis. Hasil diskusi dalam suasana yang akrab dan santai ini dijadikan sebagai kontrak pelaksanaan supervisi antara guru dan kepala sekolah.

Pelaksanaan tahap classroom observation atau observasi kelas dilaksanakan sesuai dengan kesepakatan masing-masing guru dengan kepala sekolah. Teknis pelaksanaan tahap ini di SD Al Irsyad Al Islamiyyah Malang, yaitu dengan cara guru beserta kepala sekolah memasuki ruangan bersama-sama di dalam kelas dan selanjutnya guru memperkenalkan kepala sekolah sebagai teman belajar di dalam kelas pada hari itu. Selanjutnya kepala sekolah selaku supervisor menempati posisi yang nyaman (kadang di belakang peserta didik, kadang di sisi kanan atau kiri peserta didik). Guru memulai pelajaran di dalam kelas seperti biasa sementara kepala sekolah mengamati kegiatan pembelajaran yang sedang dilaksanakan oleh guru sesuai dengan instrumen yang telah dibuat oleh guru dan disepakati oleh kedua belah pihak. Guru yang disupervisi terlihat santai dan tidak gugup ketika kegiatan observasi ini dilaksanakan. Hal ini dikarenakan pada tahap pre conference, guru dan kepala sekolah mampu memanfaatkan tahapan tersebut untuk menciptakan suasana yang hangat dan akrab, sehingga pada saat kegiatan pengamatan 
di kelas baik supervisor (kepala sekolah) maupun guru dapat menjalankan peran masing-masing secara maksimal dan alasmiah.

Tahapan lanjutan pada proses supervisi klinis yaitu tahap post observation atau yang biasa disebut dengan tahap episode pertemuan balikan. Tahapan ini disepakati oleh guru di SD Al Irsyad Al Islamiyyah Malang beserta kepala sekolah sesegera mungkin guna menjaga ingatan yang masih segar dalam ingatan terkait proses pembelajaran yang telah dilaksanakan. Suasana yang terjadi di setiap episode pertemuan balikan di masing-masing guru yaitu terbuka, hangat, dan tidak terkesan kaku seperti penilaian kinerja yang kebanyakan ditakuti oleh pegawai. Keseluruhan episode pertemuan balikan dilaksanakan bukan dalam rangka mengadili, menilai, atau mendikte guru akan tetapi kepala sekolah memberikan kesempatan kepada guru yang disupervisi untuk menyatakan poin-poin apa saja yang dirasa menjadi kelebihan dan kekurangan dirinya sendiri selama proses mengajar secara mandiri sekaligus menceritakan perasaan yang dirasa selama melaksanakan kegiatan supervisi. Setelah guru melakukan hal tersebut, kemudian supervisor melanjutkan dengan review pengamatan melalui instrumen dan catatan yang telah dibuat. Beberapa guru juga nampak diperlihatkan rekaman video dirinya mengajar oleh kepala sekolah, sehingga konfirmasi tersebut bisa dilihat ulang oleh guru yang bersangkutan. Pada kesempatan inilah, saran perbaikan dapat muncul dari kedua belah pihak.

Guru diberikan pancingan untuk menemukan sendiri perbaikan untuk cara mengajar yang lebih baik disamping kepala sekolah juga secara langsung memberikan saran perbaikan berdasarkan hasil pengamatannya. Saran dan perbaikan yang muncul dapat berupa penyempurnaan RPP, penambahan strategi mengajar, inovasi model pembelajaran, inovasi metode pembelajaran, inovasi dalam menciptakan alat peraga pembelajaran, maupun terkait manajemen kelas dan manajemen waktu seorang guru ketika melakukan pembelajaran di dalam kelas. Kegiatan supervisi klinis di SD Al Irsyad Al Islamiyyah Malang ini dilaksanakan dalam rangka membantu guru untuk mengatasi permasalahan dan kesulitan dalam mengajar agar sesegera mungkin dapat tercipta lingkungan belajar yang menyenangkan bagi semua warga sekolah sehingga diharapkan prestasi peserta didik dapat meningkat dan kemampuan guru dalam melaksanakan pembelajaran juga semakin profesional.

\section{Pelaksaan Kegiatan Lesson Study di Universitas Negeri Malang}

Permasalahan terkait pembelajaran yang dialami oleh guru dan peserta didik di tingkat pendidikan dasar, juga terlihat di jenjang pendidikan tinggi. Fenomena terbaru di jenjang pendidikan tinggi dalam rangka memberikan bantuan profesional kepada pendidik saat ini adalah maraknya praktik lesson study oleh dosen muda dalam rangka meningkatkan kompetensi profesionalnya sebagai dosen pemula di lingkungan perguruan tinggi. Kasus tersebut juga dapat dilihat di Universitas Negeri Malang (UM). Beberapa kegiatan lesson study diikuti oleh peneliti di 3 (tiga) kampus UM, yaitu kampus pusat UM berada di Jalan Semarang Nomor 5 Malang, kampus dua yang berada di daerah Sawojajar, dan yang ketiga adalah kampus UM yang berada di Blitar.

Proses lesson study yang dilaksanakan di UM yaitu dengan cara dosen senior diberikan tanggung jawab untuk memantau perkembangan dan memberikan bimbingan terhadap kelompok dosen muda dalam aktivitasnya melakukan pembelajaran. Proses tersebut berupa siklus, yaitu plan, do, dan see. Diawali dengan kelompok dosen muda yang terdiri dari beberapa rumpun mata kuliah yang berbeda membuat perencanaan terkait perangkat pembelajaran yang akan diajarkan pada masing-masing mata kualiah untuk disepakati bersama sebelum dipraktikkan dalam kelas. Setelah kesepakatan terkait perangkat pembelajaran, kemudian disepakati pula yang bertugas sebagai dosen model dan observer berdasarkan jadwal mengajar masing-masing. Kemudian tahap do dilaksanakan, yaitu proses pembelajaran di dalam kelas. Dosen model yang bertugas segera mengambil posisi untuk melaksanakan pembelajaran berdasarkan RPP dan perangkat pembelajaran lain yang telah disepakati, sedangkan observer (dosen muda dan satu dosen senior sebagai pembimbing) beserta mahasiswa peneliti juga ikut terlibat dan mengambil posisi sebagai observer untuk mengamati keterlibatan mahasiswa selama mengikuti proses perkuliahan dosen model. 
Setelah tahapan do dilaksanakan, maka tahapan selanjutnya adalah evaluasi yang dikemas dalam bentuk forum lingkaran kecil untuk konfirmasi proses pembelajaran yang telah dilaksanakan oleh dosen model. Pada kesempatan ini terjadi diskusi yang dimulai dari satu persatu observer memberikan masukan atas pengamatan yang telah dilaksanakan berdasarkan pembelajaran dosen model. Dosen model mendengarkan dengan serius dan mencatat setiap masukan dan catatan yang diberikan oleh masing-masing observer, selanjutnya adalah dosen model memberikan konfirmasi dari setiap catatan yang diberikan oleh observer. Kemudian terakhir adalah kesimpulan dan kesepakatan perbaikan yang diberikan oleh dosen pembimbing (dosen senior) untuk perbaikan mengajar selanjutnya.

Tidak berbeda dengan permasalahan pembelajaran di jenjang sekolah dasar, di jenjang perguruan tinggi juga memiliki dua sumber permasalahan yaitu dari diri mahasiswa dan dari diri dosen pengampu mata kuliah. Permasalahan yang bersumber dari mahasiswa diantaranya fokus mahasiswa tidak mengarah pada penjelasan dosen (perkualiahan) melainkan berfokus pada handpone (HP) atau gadget yang sedang dibawa, sumber belajar yang berupa segala referensi juga mampu memicu masalah baru yaitu HP yang disalahfungsikan oleh mahasiswa. Masalah lainnya yaitu terjadi pada saat proses diskusi kelompok, beberapa dari kelompok melakukan komunikasi dengan sesama anggota di luar materi bahasan kelompok, sehingga tidak mengikuti keseluruhan proses diskusi kelompok seperti yang diinginkan oleh dosen, selain masalah tersebut ketertarikan mahasiswa untuk mengikuti perkuliahan dinilai kurang.

Hal ini dibuktikan dengan adanya salah satu dosen yang sudah mengirimkan materi pembelajaran yang akan diajarkan melalui email akan tetapi keseluruhan mahasiswa di dalam kelas tidak mampu menjawab pertanyaan kuis yang diberikan oleh dosen hal ini dikarenakan tidak ada satupun mahasiswa yang mengakses dan mempelajari materi ajar yang telah dikirimkan oleh dosen melalui email, masalah selanjutnya yaitu sikap tidak percaya diri oleh sebagian mahasiswa masih kurang pada mata kuliah praktik hal ini dapat dilihat ketika praktik gerakan tari satu persatu oleh mahasiswa masih memerlukan panggilan berkali-kali untuk beberapa mahasiswa sehingga fenomena ini dapat menyita waktu dosen untuk melanjutkan pelajaran di aspek yang lain, dan masalah klasik lainnya adalah kegaduhan mahasiswa ketika melaksanakan pembelajaran kelas praktik yang sulit dikendalikan oleh dosen.

Permasalahan sumber kedua yaitu bersumber dari dosen pengampu mata kuliah yang melaksanakan lesson study. Peneliti dapat menangkap beberapa permasalahan yang muncul baik pada saat proses pembelajaran maupun pada tahapan konfirmasi setelah pembelajaran (tahap lesson study). Masalah yang muncul diantaranya yaitu ketidakjelasan komunikasi yang disampaikan oleh dosen pengajar pada pertemuan-pertemuan sebelumnya sehingga mahasiswa missed communication terkait materi pelajaran yang disampaikan pada hari itu, kurang komunikatifnya suara yang dikeluarkan oleh dosen pengajar (terlalu pelan) sehingga mahasiswa bagian belakang tidak dapat mendengarkan penjelasan materi yang diajarkan, dan munculnya rasa gugup dari dosen pengajar matakuliah praktik karena kekhawatiran kekurangan waktu untuk melaksanakan proses pembelajaran secara tuntas. Adapula satu permasalahan yang dianggap serius yaitu ketika tahap observasi kolegial terhadap dosen model, beberapa observer dari pihak dosen sejawat juga terlihat sibuk memainkan HP atau gadget yang dimiliki sehingga ketika tahap pertemuan konfirmasi terlihat dosen yang bersangkutan kurang maksimal dalam memberikan komentar yang berisi saran, masukan, dan kesimpulan pengamatan terhadap dosen model. Hal ini dapat menimbulkan kerugian oleh dosen model dikarenakan apa yang ditampilkan tidak dapat diberikan masukan perbaikan secara positif oleh observer.

\section{PEMBAHASAN}

\section{Pelaksanaan Kegiatan Supervisi Klinis di SD Al Irsyad Al Islamiyyah Malang}

Temuan penelitian menunjukkan bahwa permasalahan yang terjadi pada proses pembelajaran bersumber dari dua subjek yaitu diri peserta didik dan diri guru berkaitan dengan kemampuan profesionalnya. Permasalahan yang dialami guru apabila dibiarkan secara terus- 
menerus akan berakibat pada banyak hal yaitu kemampuan peserta didik yang kurang maksimal, kemampuan guru tidak berkembang, mutu lembaga menjadi buruk, dan kualitas pendidikan secara global juga akan menurun. Kepala sekolah menganggap pelaksanaan supervisi klinis dapat dianggap sebagai solusi bantuan profesi kepada guru yang memiliki semangat dan inovasi untuk senantiasa memperbaiki kualitasnya.

Pendapat yang dipaparkan oleh Adams dan Dcikey ini sejalan dengan pelaksanaan supervisi klinis di suatu lembaga pendidikan bahwasanya program yang dirancang untuk memperbaiki kualitas pengajaran pada hakikatnya adalah perbaikan secara menyeluruh terkait situasi belajar, manajemen kelas, manajemen waktu, serta perbaikan pada sisi kemampuan guru ketika melaksanakan kegiatan pembelajaran di dalam kelas (Sahertian, 2010; Gunawan, dkk., 2017). Hal senada dipaparkan oleh Boardman bahwasanya pelaksanaan supervisi di sekolah merupakan wujud dari usaha untuk memberikan stimulus, mengkoordinasi, dan memberikan bimbingan secara berkelanjutan oleh kepala sekolah (supervisor) bagi perkembangan guru (pendidik) di sekolah dalam memperbaiki kualitas pengajaran. Teknik supervisi ini dapat dilakukan secara individu maupun kelompok (Sahertian, 2010; Gunawan, 2011).

Temuan selanjutnya terkait dengan pelaksanaan supervisi klinis secara teknis yaitu berkaitan dengan prosedur atau tahapan yang dilaksanakan. Dari keseluruhan tahapan dimulai dari pre conference, classroom observation, dan post observation. Semuanya dilaksanakan dalam suasana yang hangat dan akrab antara guru dan kepala sekolah. Subjek utama yang berperan di setiap tahapan adalah guru yang akan disupervisi. Kepala sekolah memberikan kebebasan dan kesempatan kepada guru untuk mengutarakan pendapat, keluhan, dan perasaan secara lebih dulu sehingga dengan sabar dan penuh perhatian kepala sekolah mencatat setiap detail penjelasan dari guru. Kontrak instrument yang telah disepakati menjadi acuan supervisor untuk melaksanakan pengamatan selama proses observasi di dalam kelas. Pertemuan balikan yang berlangsung menjadi momen untuk memberikan masukan perbaikan kepada guru yang disupervisi sehingga harapan selanjutnya adalah guru tersebut telah mengetahui kekurangannya dalam melakukan proses pengajaran dan menerapkan pola perbaikan hasil dari proses supervisi untuk meningkatkan kualitas pembelajaran yang dilakukan.

Kondisi demikian selaras dengan pendapat dari Weller bahwasanya fokus pelaksanaan kegiatan supervisi yaitu pada kualitas pengajaran dengan cara yang sistematis (Nurtain, 1989). Proses tersebut meliputi perencanaan, pengamatan (observasi), dilanjutkan dengan analisis intelektual yang continoue terhadap performansi guru ketika melakukan pembelajaran secara riil di kelas dalam rangka melakukan perbaikan dan perubahan secara rasional dan ilmiah sesuai masalah yang nyata terjadi. Hal senada pula pendapat yang sejalan dengan pelaksanaan supervisi klinis di SD Al Irsyad Al Islamiyyah yaitu menurut Sergiovanni yang menyatakan bahwa supervisi pembelajaran melalui pendekatan klinis merupakan aktivitas pertemuan tatap muka secara langsung antara supervisor (kepala sekolah atau pengawas) dengan guru terhadap pelaksanaan pembelajaran di dalam kelas guna melakukan perbaikan dan pengembangan kemampuan profesional guru (Imron, 2012; Gunawan, 2015).

Berdasarkan bahasan teoritis tersebut, bisa disimpulkan bahwasanya pelaksanaan supervisi dalam hal ini adalah supervisi klinis dimaksudkan untuk memberikan bantuan bimbingan profesi kepada guru dan pegawai yang lain dalam rangka meningkatkan kemampuan profesionalnya guna memberikan layanan pembelajaran terbaik kepada seluruh siswa untuk mencapai tujuan pembelajaran yang ditetapkan. Maksudnya adalah untuk mengatasi dan memberikan solusi terbaik terhadap kesulitan-kesulitan guru di lapangan sehingga kondisi pembelajaran yang idel (efektif dan efisien) dapat benar-benar tercapai setelah melaksanakan supervisi klinis.

\section{Pelaksanaan Kegiatan Lesson Study di Universitas Negeri Malang}

Lesson study yang dilakukan oleh dosen model UM sejalan dengan pendapat yang dipaparkan oleh Lewis (2002) yaitu merencanakan (plan), mengamati (observe), dan melakukan refleksi (see). Keseluruhan tahapan tersebut masingmasing memberikan gambaran tentang proses 
kolaborasi antar guru-guru atau dosen-dosen dalam kesinambungan tujuan yaitu perbaikan kualitas mengajar. Memperdalam makna dari lesson study dari pemaparan Lewis, pendapat lain terkait makna tahapan lesson study dipaparkan oleh Jalal (2007) dan Gunawan (2017), yang menyatakan ketiga tahapan lesson study tersebut dilaksanakan berdasarkan prinsip kolegalitas dari teman sejawat/rekan kerja/kolega dan mutual learning (saling belajar satu sama lain) untuk membangun komunitas belajar yang saling membangun.

Berkaitan dengan teknik pelaksanaannya, masih berkesinambungan juga dengan pendapat dari Yusac (2007) bahwasanya ciri-ciri utama lesson study diantaranya adalah: (1) rekan kerja antarguru diberikan kesempatan secara nyata untuk dapat terlibat langsung menyaksikan dan mengamati proses pembelajaran di dalam kelas oleh rekan guru lain yang berperan sebagai guru model; (2) guru model harus senantiasa mampu mengkondisikan peserta didik agar senantiasa menjadi pusat kegiatan pengembangan profesi guru di setiap sub kegiatan pembelajaran yang dilakukan; (3) aktivitas lesson study secara keseluruhan merupakan wujud pengembangan profesi yang dikendalikan sendiri oleh guru; dan (4) dan lesson study memungkinkan para guru mengambil peran utama yaitu sebagai subjek yang diteliti pada praktik pembelajaran di kelasnya sendiri dan menjadikan guru model sebagai observer (peneliti) dan pemikir yang mandiri tentang suatu konsep manajemen pembelajaran yang matang dan dinilai efektif sesuai kacamata observer yang juga memahami standar pembelajaran yang benar.

\section{Integrasi Pelaksanaan Supervisi Klinis dan Lesson Study sebagai Upaya Meningkatkan Kemampuan Profesional Guru dalam Menciptakan Pembelajaran Efektif}

Upaya meningkatkan kemampuan profesional guru untuk menciptakan pembelajaran yang efektif berdasarkan penelitian yang telah dilaksanakan dapat ditempuh melalui model integrasi pelaksanaan supervisi klinis dan lesson study. Model integrasi baru tersebut diharapkan dapat menjawab permasalahan pembelajaran yang berupa kesulitan dan hambatan yang dialami oleh guru sekolah dasar dalam melaksanakan pembelajaran di kelas. Model integrasi baru antara supervisi klinis dan lesson study yang telah diterapkan di perguruan tinggi (Universitas Negeri Malang) dapat pula diadopsi untuk dilaksanakan di lembaga pendidikan tingkat dasar. Model integrasi tersebut dapat dilihat melalui Gambar 1.

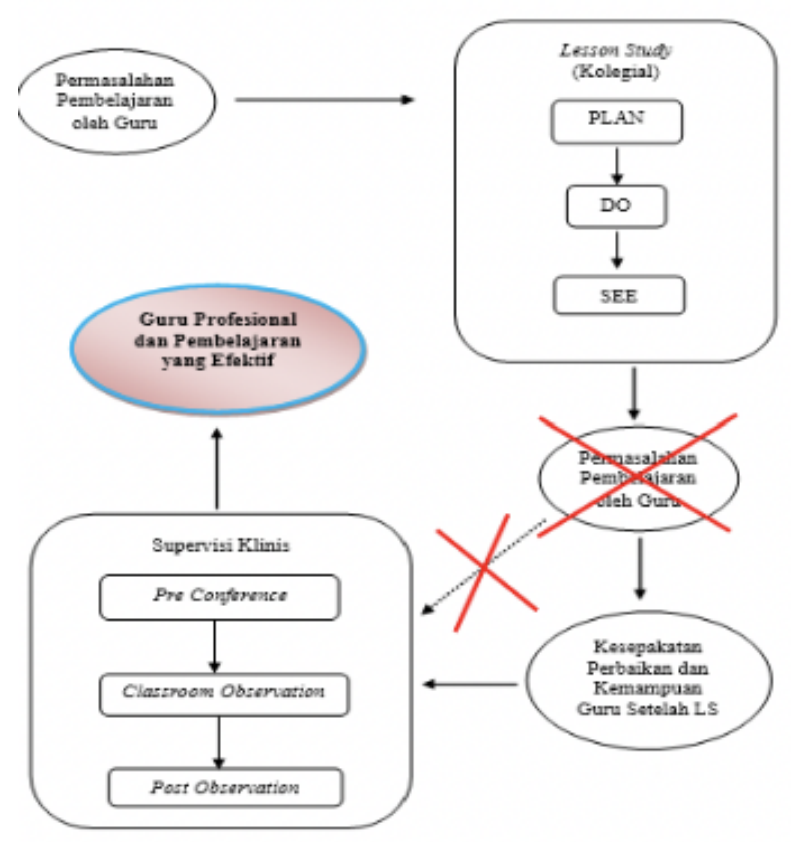

\section{Gambar 1 Model Integrasi Supervisi Klinis dan Lesson Study}

Integrasi baru pada Gambar 1 dijelaskan bahwasanya pelaksanaan supervisi klinis dan lesson study dapat diintegrasikan menjadi satu model baru yang bermakna tahapan berlanjut dalam rangka peningkatan kompetensi profesional guru dalam menciptakan pembelajaran yang efektif di jenjang sekolah dasar. Tahapan dari model ini diawali dengan proses lesson study dan dilanjutkan dengan tahap supervisi klinis. Bahan kajian pada tahap lesson study adalah permasalahan guru sekolah dasar dalam melaksanakan pembelajaran di kelas. Permasalahan tersebut dibagi berdasarkan rumpun mata pelajaran yang diajarkan. Sebut saja dalam sekolah dasar umumnya adalah rumpun guru kelas, rumpun guru Pendidikan Agama Islam (PAI), rumpun guru Pendidikan Jasmani dan Keolahragaan (PJOK), dan rumpun guru Bahasa Inggris.

Contoh permasalahan riil pada pembelajaran di kelas yang dilaksanakan oleh masing-masing guru yang dapat dijadikan bahan kajian proses lesson study diantaranya yaitu kesiapan guru dalam membuat perangkat pembelajaran dapat 
didiskusikan bersama oleh kelompok lesson study, kendala dari kegaduhan peserta didik dalam kelas, kurangnya konsentrasi dan ketertarikan peserta didik untuk mengikuti pembelajaran, manajemen waktu oleh guru yang berlebih, sumber belajar berupa alat elektronik (HP) yang disalahfungsikan, dan yang lainnya. Permasalahan-permasalahan tersebut di bawa sebagai kajian lesson study untuk dilaksanakan pada proses plan-do-see. Tahapan kedua setelah berakhirnya siklus lesson study adalah menghasilkan kesepakatan perbaikan terhadap guru model berdasarkan hasil pengamatan observer (guru lainnya) secara kolegial. Hasil tersebut diharapkan menjadi saran perbaikan bagi performansi guru saat mengajar dengan perbaikan yang terlihat.

Memasuki tahapan berikutnya yaitu tahap supervisi klinis. Bahan kajian yang menjadi bekal pada pertemuan pre conference oleh supervisor (kepala sekolah)danguruadalahberupakemampuan guru yang baru dari hasil analisis perbaikan dan peningkatan guru model yang merupakan produk dari tahapan sebelumnya (lesson study). Berbeda dengan supervisi klinis pada umumnya, yang menjadi bahan diskusi selama proses pre conference adalah berupa permasalahan/kendalakendala yang dihadapi oleh guru, akan tetapi pada model integrasi ini adalah kemampuan baru berupa saran perbaikan pengajaran yang dihasilkan dari kegiatan tahap satu (lesson study) menjadi bahan kajian supervisor dan guru. Proses supervisi klinis dilanjutkan hingga akhir seperti proses supervisi klinis biasanya, sehingga di hasil akhir model integrasi tersebut diharapkan menghasilkan guru profesional yang sesuai dengan standar kompetensi profesional dalam rangka menciptakan suasana pembelajaran yang efektif baik itu dilakukan oleh guru baru (pemula) maupun oleh guru yang sudah senior di jenjang sekolah dasar.

\section{KESIMPULAN DAN SARAN}

\section{Kesimpulan}

Simpulan yang dihasilkan dari hasil penelitian tersebut dalam rangka meningkatkan profesionalisme guru sekolah dasar guna mewujudkan pembelajaran yang efektif dapat melalui teknik supervisi klinis, lesson study, dan integrasi kedua teknik tersebut. Subjek dari teknik integrasi antara supervisi klinis dan lesson study yaitu guru sekolah dasar yang sesuai dengan rumpunnya, yaitu rumpun guru kelas, rumpun guru Pendidikan Agama Islam (PAI), rumpun guru Pendidikan Jasmani dan Keolahragaan (PJOK), dan rumpun guru Bahasa Inggris. Keunikan dari teknik integrasi ini adalah teknik yang dilakukan secara berkelanjutan, dengan perbedaan bekal bahan kajian pada tahapan teknisnya. Tahap awal dilakukan teknik ini adalah lesson study dengan bahan kajian permasalahan guru selama melaksanakan pembelajaran yang selanjutnya menghasilkan kontrak perbaikan dan peningkatan kualitas maengajar melalui rekomendasi perbaikan. Hasil dari tahap tersebut dijadikan bahan kajian pada tahap selanjutnya yaitu pelaksanaan supervisi klinis yang diharapkan dapat menghasilkan guru yang profesional dengan pembelajaran yang efektif dan efisien.

\section{Saran}

Temuan penelitian yang didapatkan oleh peneliti dapat ditindaklanjuti untuk diimplementasikan oleh beberapa pihak. Berdasarkan hal tersebut, saran yang diajukan kepada Kepala Dinas Pendidikan Kota Malang agar dapat menyelenggarakan pelatihan dan seminar terkait integrasi model supervisi klinis dan lesson study sebagai teknik baru dalam rangka meningkatkan kemampuan profesional guru dalam mewujudkan pembelajaran yang efektif. Saran kepada kepala sekolah pada jenjang pendidikan dasar, agar dapat menerapkan teknik ini di masingmasing lembaga yang dipimpin. Saran bagi peneliti lain adalah agar temuan penelitian ini dijadikan bahan kajian dan referensi lanjutan sehingga dapat memperdalam penelitian yang sejenis sehingga menghasilkan penelitian yang lebih baik manfaatnya.

\section{DAFTAR RUJUKAN}

Gunawan, I. 2011. Pendekatan Alternatif dalam Pelaksanaan Supervisi Pengajaran. Premiere Educandum, 1(2), 211-232.

Gunawan, I. 2014. Metode Penelitian Kualitatif: Teori dan Praktik. Jakarta: PT Bumi Aksara.

Gunawan, I. 2015. Mengembangkan Alternatifalternatif Pendekatan dalam Pelaksanaan 
Supervisi Pengajaran. Manajemen Pendidikan, 24(6), 467-482.

Gunawan, I. 2017. Penerapan Manajemen Pembelajaran Berbasis Lesson Study dan Dampaknya terhadap Keaktifan Mahasiswa dalam Perkuliahan. Jurnal Pendidikan dan Pembelajaran, 24(1), 126-138.

Gunawan, I., Alifiyah, I., dan Evananda, F. 2017. Kompetensi Guru Sekolah Dasar: Sebuah Analisis Reflektif dengan Teknik Supervisi Pengajaran Penilaian Diri Sendiri. Prosiding Seminar Nasional Sinergitas Keluarga, Sekolah, dan Masyarakat dalam Penguatan Pendidikan Karakter, Fakultas Ilmu Pendidikan Universitas Negeri Malang, Malang, hlm. 249-258.

Imron, A. 2012. Peningkatan Profesionalisme Guru Sekolah Dasar dalam Kerangka Manajemen Peningkatan Mutu Berbasis Sekolah. Jakarta: PT Bumi Aksara.

Jalal. 2007. Perkembangan Pelaksanaan Program Lesson Study. Bandung: Remaja Rosdakarya. Lewis, C. 2002. Educating Hearts and Minds: Reflections on Japanese Preschool and Elementary Education. NewYork: Cambridge University Press.
Miles, M. B., Huberman, A. M., dan Saldana, J. 2014. Qualitative Data Analysis: A Methode Sourcebook. New York: SAGE Publications, Inc.

Nur, D. 2013. Metode Pembelajaran Lesson Study. Bandung: Remaja Rosdakarya.

Nurtain, H. 1989. Supervisi Pengajaran: Teori dan Praktik. Jakarta: Dirjendikti Depdikbud.

Sahertian, P. A. 2010. Konsep Dasar dan Teknik Supervisi Pendidikan dalam Rangka Pengembangan Sumber Daya Manusia. Jakarta: Rineka Cipta.

Saputra, U. 2006. Administrasi Pendidikan. Jakarta: Rineka Cipta.

Ulfatin, N. 2015. Metode Penelitian Kualitatif di Bidang Pendidikan: Teori dan Aplikasinya. Malang: Media Nusa Creative.

Undang-undang Nomor 14 Tahun 2005 tentang Guru dan Dosen. 2010. Jakarta: Fokus Media. Yusac. 2007. Kebersamaan melalui Lesson Study. Bali: Bali Pos. 